\title{
HJKK
}

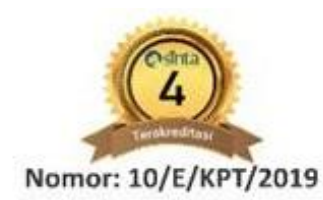

INFORMASI ARTIKEL

Received: July, 05, 2021

Revised: July, 13, 2021

Available online: July, 14, 2021

at : http://ejurnalmalahayati.ac.id/index.php/holistik

\section{Pola asuh orang tua pada remaja dengan kecanduan internet}

\author{
Janet Tri Bibelia, Nur Oktavia Hidayati* ${ }^{\star}$ Irman Somantri
}

Fakultas Keperawatan, Universitas Padjadjaran Bandung, Jawa Barat

Korespondensi Penulis: Nur Oktavia Hidayati. *Email: nur.oktavia@unpad.ac.id

\section{Abstract \\ Parenting Style among Teenagers with an Internet Addiction}

Background: Teenagers are transition from childhood to adulthood which is a period of crisis against maladaptive risks, such as internet addiction. One of the external factors that most influences internet addiction in teenagers is parenting style.

Purpose: To describe the parenting style among teenagers with an internet addiction.

Method: A quantitative descriptive with a cross-sectional approach. The population was all students in grades of $X$ and $\mathrm{XI}$ grade senior high school of Jatinangor, and samples were taken by purposive sampling with criteria of experiencing internet addiction, have complete parents, and living with parents with a total sample of 100 students. Data collection by using an instrument of Parental Authority Questionnaire (PAQ) which has translated in bahasa and tested for its validity with coefficient $\leq 0.300$, and its reliability with of Alpha Cronbach $\leq 0.700$. The results were analyzed by univariate.

Results: The research showed that authoritative father's parenting style perceived by teenagers $(38 \%)$, authoritative mother's parenting style perceived by teenagers (43\%), authoritarian father's parenting style perceived by teenagers $(25 \%)$, authoritarian mother's parenting style perceived by teenagers $(28 \%)$, permissive father's parenting style perceived by teenagers $(28 \%)$, and permissive mother's parenting style perceived by teenagers $(16 \%)$.

Conclusion: Most of the parenting styles perceived by adolescents with internet addiction are democratic maternal.

\section{Keywords: Internet addiction; Parent style; Teenagers.}

Pendahuluan: Masa remaja merupakan masa transisi dari anak-anak menuju dewasa yang merupakan masa krisis terhadap risiko maladaptif, seperti kecanduan internet. Salah satu faktor eksternal yang paling mempengaruhi kecanduan internet pada remaja ialah pola asuh..

Tujuan: Mengetahui gambaran pola asuh orang tua pada remaja dengan kecanduan internet.

Metode: Penelitian deskriptif-kuantitatif dengan pendekatan cross sectional. Populasi pada penelitian ini ialah seluruh siswa kelas X dan XI SMA Negeri Jatinangor, sebanyak 838 siswa. Teknik pengambilan sampel adalah purposive sampling dengan kriteria inklusi mengalami kecanduan internet, orang tua lengkap dan tinggal bersama orang tua dengan jumlah sampel sebanyak 100 siswa. Pengumpulan data dilakukan dengan menggunakan Instrumen Parental Authority Questionnaire (PAQ) yang telah dialih bahasakan dan diuji validitasnya dengan nilai koefisien $\leq 0.300$, serta reliabilitasnya dengan nilai Alpha Cronbach $\leq 0.700$. Hasil penelitian dianalisis dengan teknik analisis univariat.

Hasil: Hasil penelitian menunjukkan pola asuh ayah demokratis yang dipersepsikan remaja (38\%), pola asuh ibu demokratis yang dipersepsikan remaja $(43 \%)$, pola asuh ayah otoriter yang dipersepsikan remaja $(25 \%)$, pola 
asuh ibu otoriter yang dipersepsikan remaja (28\%), pola asuh ayah permisif yang dipersepsikan remaja (28\%), dan pola asuh ibu permisif yang dipersepsikan remaja $(16 \%)$.

Simpulan: Sebagian besar pola asuh yang dipersepsikan remaja dengan kecanduan internet adalah pola asuh ibu demokratis.

\section{Kata Kunci: Kecanduan internet; Pola asuh; Orang tua; Remaja.}

\section{PENDAHULUAN}

Teknologi saat ini telah berkembang sangat pesat dan mudah didapatkan. Salah satu bentuk teknologi yang terus menerus mengalami kemajuan secara pesat ialah internet. Internet bukanlah suatu hal yang asing pada zaman dengan kemajuan teknologi sekarang ini, dimana internet menjadi sesuatu yang sangat populer dan diperlukan banyak orang. Berdasarkan situs yang bernama Internet World Stats (2017), Indonesia merupakan negara pengguna internet terbesar kelima di dunia yakni sebesar 143.260 .000 . Pulau Jawa merupakan pulau terbanyak pertama pengguna internetnya, yakni sebesar $58,08 \%$ dari total penduduk Indonesia (Asosiasi Penyelenggara Jasa Internet Indonesia, 2017). Provinsi Jawa Barat merupakan Provinsi yang paling banyak pengguna internetnya, yakni sebesar 16,4 juta jiwa (APJII, 2014).

Berdasarkan kelompok usia, survei yang dilakukan oleh Marketeers (2013) menunjukkan pengguna internet di Indonesia usia 15 tahun hingga 22 tahun berkisar 42,4\%. Data statistik penetrasi pengguna internet berdasarkan usia yang dilaporkan oleh APJII (2017) menunjukkan bahwa usia 13-18 tahun berada pada peringkat tertinggi pertama yaitu sebesar $75,50 \%$. Sebanyak $70 \%$ remaja menggunakan internet dengan ratarata waktu yang dihabiskan sekitar 2 jam 30 menit setiap harinya untuk bermain game online dan mengakses media sosial melalui smartphone dan 5 jam 30 menit melalui laptop (Turkle, 2011). Berdasarkan status pendidikannya, pengguna internet paling banyak di Indonesia adalah SMA sederajat (APJII, 2014). Melihat data mengenai pesatnya perkembangan internet di Indonesia dan banyaknya jumlah pengguna internet di Indonesia, khususnya pada remaja, dapat disimpulkan bahwa setiap tahunnya akan mengalami peningkatan.

Remaja ialah seseorang yang secara bertahap mengalami perubahan dari masa saat ia kanakkanak menuju kedewasaan, perubahan tersebut menjadikan masa remaja rentan mengalami berbagai persoalan yang berhubungan dengan emosi. Hal ini disebabkan oleh ciri-ciri dari emosi remaja, khususnya remaja tengah yang mudah mengalami perubahan emosi seperti sedih dan putus asa, lalu cenderung melawan dan memberontak, dimana remaja tengah akan sangat memperhatikan penampilan, memiliki rasa ingin tahu yang tinggi, mudah terpengaruh oleh teman sebaya, sangat perhatian terhadap lawan jenis, serta mulai memperluas pertemanan baik secara langsung maupun melalui media (Qomariyah, 2009; Sarwono, 2011). Sebagian remaja bisa menghadapi masa ini dengan baik, tetapi beberapa remaja tidak mampu mengatasinya, sehingga hal tersebut kerap akan menimbulkan permasalahan bagi remaja.

Masalah-masalah yang tidak mampu diatasi tersebut menyebabkan terjadinya perilaku menyimpang yang dilakukan oleh remaja atau kerap dikenal dengan kenakalan remaja, salah satu bentuk perilaku menyimpang yang saat ini banyak terjadi di kalangan remaja ialah kecanduan internet. Seseorang digolongkan sebagai pecandu internet jika ia menghabiskan waktu lebih dari 40 jam per bulan atau setiap hari mengakses internet dengan rata-rata lebih dari 4 jam (Surya, 2002 dalam Qomariyah, 2009). Internet yang digunakan secara berlebihan dapat menyebabkan terjadinya masalah psikologis berupa meningkatnya gejala depresi, menghasilkan risiko lebih tinggi perilaku agresif, penurunan kinerja dan motivasi, gangguan harga diri, perilaku bunuh diri, menjadi lebih sensitif (Huang, 2009), rentan terhadap risiko yang berkaitan dengan dunia Web, seperti cyberbullying, pencurian identitas dan ajakan seksual (Trumello et al., 2018). Sedangkan, masalah sosial yang menjadi dampak dari penggunaan internet yakni penurunan kemampuan interpersonal sehingga mengalami kerenggangan dengan keluarga dan teman- teman (Hakim et al, 2016).

Selain dampak psikologis dan sosial, terdapat juga dampak pada fisik, yaitu mengalami nyeri pergelangan tangan, mata menjadi kering, migrain

Janet Tri Bibelia, Nur Oktavia Hidayati*, Irman Somantri

Fakultas Keperawatan, Universitas Padjadjaran Bandung, Jawa Barat

Korespondensi Penulis: Nur Oktavia Hidayati. *Email: nur.oktavia@unpad.ac.id 
atau sakit kepala, sakit punggung, gangguan pola makan, gangguan tidur, saraf mata, otak dan jantung terganggu, rabun jauh, berat badan berkurang akibat lupa makan, terlalu banyak duduk yang dapat mengakibatkan lambung dan ginjal rusak dan cedera tulang belakang (Rini, 2011). Dampak lain yang diakibatkan oleh kecanduan internet, yakni perkembangan anak akan terhambat dikarenakan banyaknya waktu yang dihabiskan untuk bermain internet daripada melakukan aktivitas fisik, tidak masuk sekolah, tidak mengerjakan tugas, menurunkan prestasi akademis dan menurunkan kinerja individu yang mengalaminya (Elia, 2009).

Dalam mencegah dampak negatif yang ditimbulkan akibat kecanduan internet pada anak remaja, diperlukan adanya kehadiran orang tua untuk memantau dan mengontrol penggunaan internet pada anak, agar anak memahami ancaman dan risiko dari kecanduan internet (Wasiński \& Tomczyk, 2015). Peran orang tua dalam strategi pengasuhan anak menjadi perhatian banyak publik. Hal ini dikarenakan orang tua merupakan figur penting dalam kehidupan anak (Soenens et al., 2006 dalam Morrish, 2011).

Hasil penelitian yang didapatkan oleh (Wasiński \& Tomczyk, 2015) yang menyebutkan bahwa faktor lingkungan rumah berupa kurangnya kesiapan orang tua dalam mengasuh anak merupakan faktor kunci terjadinya kecanduan internet pada remaja. Hal ini didukung oleh penelitian Masya dan Candra (2016) menyebutkan bahwa faktor paling tinggi penyebab kecanduan pada remaja ialah kurang perhatian dan kontrol dari keluarga. Penelitian tersebut juga sejalan dengan hasil penelitian yang didapatkan oleh (Lam et al., 2009) yang menyebutkan bahwa ketidakpuasan terhadap keluarga menjadi faktor anak kecanduan internet. Selain itu, berdasarkan hasil penelitian (Kusumawati, Aviani, \& Molina, 2017), ditemukan adanya perbedaan tingkat kecanduan game online pada remaja ditinjau dari gaya pengasuhan orang tuanya.

Hal lain yang dapat menyebabkan remaja menjadi kecanduan internet ialah adanya pengaruh dari teman sebaya. Dalam hal ini, orang tua dapat melakukan perannya dalam menggiring keterikatan anak dengan teman sebayanya. Orang tua dapat berperan untuk memberikan arahan kepada anak untuk memilih teman sebaya yang baik (Yang,
Zhu, Chen, Song, \& Wang, 2016).

Berdasarkan hasil penelitian-penelitian yang telah dilakukan, diperlukan adanya pengasuhan yang tepat dari orang tua untuk mencegah seorang anak mengalami kecanduan internet. Apabila orang tua menerapkan pengasuhan yang negatif, maka akan memberikan dampak, yakni menurunkan kesehatan mental anak, harga diri, kepuasan hidup anak, dan meningkatkan rasa malu yang tinggi pada anak (Mintz, Etengoff, \& Grysman, 2017; Yamawaki, Peterson, \& Omori, 2011).

Pola asuh yang ditetapkan oleh orang tua, yakni ayah dan ibu akan memiliki perbedaan. Hal ini dikarenakan adanya perbedaan peran antara ayah dan ibu dalam keluarga. Ibu memiliki peran dalam merawat dan memberikan kasih sayang, serta lebih berhubungan dengan pengasuhan dan perawatan secara fisik. Disisi lain, peran ayah dalam keluarga ialah mengasah kemampuan anak dalam menjelajah, serta hal lain yang berkaitan dengan rasional. Jika anak mendapatkan pengasuhan yang tepat dari kedua orang tua, maka berbagai permasalahan terkait penyimpangan remaja dapat dikendalikan dan dihindari (Astuti, 2013).

Setiap pola asuh yang diterapkan oleh orang tua akan dipersepsikan secara subjektif oleh remaja itu sendiri. Masing-masing remaja akan memiliki persepsi yang berbeda terhadap pola asuh orang tuanya, meskipun jenis pola asuh yang diterapkan adalah sama. Persepsi anak terhadap pola asuh orang tua merupakan hal penting, dikarenakan anak telah mengalami sendiri pengasuhan orang tua dan itu akan terus ada dalam diri anak sampai ia beranjak dewasa.

SMA Negeri Jatinangor merupakan satusatunya SMA Negeri yang ada di Kecamatan Jatinangor, sehingga menjadikan sekolah ini sebagai sekolah favorit yang banyak diminati oleh siswa-siswi di Jatinangor. Penelitian terdahulu yang dilakukan oleh Novianty (2018) terkait kecanduan internet di sekolah ini menunjukkan dari 269 siswa yang menjadi sampel, didapatkan hasil bahwa sebagian besar responden merupakan heavy users atau pengguna berat internet, baik pada weekday $(56,5 \%)$ maupun weekend $(68,4 \%)$ dengan tingkat kecanduan internet yang ringan. Aktivitas yang paling sering dilakukan oleh responden ialah mengakses media sosial dan

Janet Tri Bibelia, Nur Oktavia Hidayati*, Irman Somantri

Fakultas Keperawatan, Universitas Padjadjaran Bandung, Jawa Barat

Korespondensi Penulis: Nur Oktavia Hidayati. *Email: nur.oktavia@unpad.ac.id

DOl: https://doi.org/10.33024/hjk.v15il.4629 
bermain game online.

Berdasarkan wawancara yang dilakukan pada seorang guru Bimbingan Konseling (BK) didapatkan data pelanggaran dalam kurun waktu satu bulan terakhir, yakni terdapat 30 siswa yang ketahuan menggunakan handphone ketika kelas berlangsung dan dilakukan penyitaan, hampir setiap harinya terdapat satu orang siswa yang terlambat, tidak mengerjakan pekerjaan rumah $(P R)$, meninggalkan kelas di tengah jam pelajaran, alfa atau tidak hadir tanpa keterangan. Setelah diklarifikasi oleh pihak sekolah, ternyata hal-hal tersebut dikarenakan siswa-siswa tersebut keasyikan bermain game online dan mengakses media sosial hingga larut malam. Di antara semua siswa yang pernah melakukan pelanggaran di atas, terdapat 10 orang siswa yang sudah sering melakukan pelanggaran sehingga orang tuanya dipanggil oleh pihak sekolah. Ketika pihak sekolah menanyakan kepada orang tua dari siswa-siswi tersebut terkait pengetahuan orang tua mengenai penggunaan gadget pada anaknya, 6 dari 10 orang tua menjawab tidak mengetahui kegiatan apa saja yang dilakukan anak dengan gadgetnya dikarenakan tidak mengontrol anaknya, 3 orang tua lainnya mengetahui penggunaan gadget pada anaknya tetapi tidak mempermasalahkannya, dan 1 orang tua mengatakan bahwa ia sering memarahi anaknya ketika menggunakan gadget.

Wawancara terkait pola asuh orang tua yang dilakukan peneliti kepada 10 orang siswa SMA Negeri Jatinangor yang orang tuanya pernah dipanggil oleh pihak sekolah, didapatkan informasi bahwa 5 orang siswa mengatakan orang tuanya tidak mengetahui bahwa mereka sering tidur larut malam karena bermain game online, 4 orang siswa mengatakan bahwa orang tuanya memberikan kebebasan dalam menggunakan internet, dan satu orang siswa menuturkan bahwa orang tuanya melarang bermain game online di rumah, sehingga hampir setiap hari ia menginap dirumah temannya agar mereka bisa bermain game online bersama.

Berdasarkan fenomena di atas, maka peneliti tertarik untuk meneliti terkait pola asuh orang tua pada remaja dengan kecanduan internet di SMA Negeri Jatinangor.

\section{METODE}

Penelitian ini menggunakan metode deskriptif kuantitatif. Variable penelitian ini adalah pola asuh orang tua yang dipersepsikan remaja dengan kecanduan internet. Populasi pada penelitian ini adalah seluruh siswa kelas X dan XI SMA Negeri Jatinangor yang berjumlah 838 orang siswa. Sampel penelitian berjumlah 100 siswa, dengan teknik pengambilan sampel adalah purposive sampling. Instrumen pengumpulan data yang digunakan menggunakan kuesioner $\mathrm{PAQ}$ (Parenting Authority Questionaire) berdasarkan teori Baumrid (1971) yang kemudian dikembangkan oleh Buri (1991) dalam Henry (2010). Kuesioner tersebut memiliki 30 item pernyataan yang terdiri dari 10 pernyataan terkait pola asuh demokratis, 10 pernyataan terkait pola asuh otoriter, dan 10 pernyataan terkait pola asuh permisif yang menggunakan skala Likert dengan pilihan jawaban : $1=$ sangat tidak setuju, $2=$ tidak setuju, 3 = cukup setuju, $4=$ setuju, dan 5 = sangat setuju.

Kuesioner Parenting Authority Questionaire (PAQ) adalah instrumen baku yang telah diuji validitasnya pada 127 mahasiswa yang bersedia mengisi kuesioner. Uji validitas yang dilakukan merupakan uji validitas konstruk dengan uji koefisien korelasi. Dimana didapatkan hasil bahwa ibu otoriter berbanding terbalik dengan ibu permisif $(r=-0,38, p<0,0005)$ dan ibu demokratis $(r=-$ $0,48, p<0,0005)$. Demikian pula ayah otoriter berbanding terbalik dengan ayah permisif $(r=$ $0,50, p<0,0005)$ dan ayah demokratis $(r=-0,52, p$ $<0,0005)$. Selain itu, ibu permisif tidak memiliki hubungan yang signifikan dengan ibu demokratis $(r$ $=-0,7, p>0,10$ ), dan ayah permisif tidak ada hubungan signifikan dengan ayah demokratis $(r=-$ $0,12, p>0,10)$. Hasil uji tersebut menunjukkan bahwa instrumen tersebut valid. Uji reliabilitas dengan Alpha Cronbach $\leq 0.700$ yang berarti kurang reliabel. Analisis data yang digunakan adalah analisa univariat yang disajikan dalam bentuk distribusi frekuensi. Surat layak etik didapatkan dari Fakultas Keperawatan Universitas Padjadjaran dengan nomor Etik No 557/UN.6/KEP/EC/2019. 


\section{HASIL}

Tabel 1. Karakteristik Responden ( $\mathrm{N}=100)$

\begin{tabular}{lcc}
\hline Karakteristik & Frekuensi (f) & Persentase (\%) \\
\hline Jenis Kelamin & 36 & 36 \\
Laki-laki & 64 & 64 \\
Perempuan & & \\
& 14 & 14 \\
Pendidikan Ayah & 13 & 13 \\
SD SMP & 73 & 73 \\
SMA sederajat & & \\
Perguruan Tinggi & & \\
& 31 & 31 \\
Pendidikan lbu & 27 & 27 \\
SD SMP & 42 & 42 \\
SMA sederajat & & \\
Perguruan Tinggi & 95 & 95 \\
& 5 & 5 \\
Fasilitas yang paling sering digunakan & & \\
Handphone & & 49 \\
Laptop & 49 & 51 \\
Tujuan Penggunaan & 51 & \\
Bermain game & & \\
Media sosial &
\end{tabular}

Berdasarkan tabel 1. diperoleh data karakteristik demografi responden. Dari total 100 responden, lebih dari setengah responden merupakan perempuan, yakni sebanyak 64\%, pada data pendidikan orang tua, pada kelompok ayah didapatkan hasil lebih dari setengah berpendidikan SMA 65\%, sementara kelompok ibu 40\% berpendidikan SMA. Penggunaan internet, lebih dari setengah responden mengakses internet untuk media sosial $51 \%$ dengan sebagian besar menggunakan handphone $95 \%$.

Tabel 2. Distribusi Ferekuensi Pola Asuh Orang Tua

\begin{tabular}{lcc}
\hline \multicolumn{1}{c}{ Jenis Pola Asuh } & Frekuensi (f) & Persentase (\%) \\
\hline Pola Asuh Ayah & 38 & \\
Demokratis & 25 & 38 \\
Otoriter & 28 & 25 \\
Permisif & 9 & 28 \\
Undifferentiated & & 9 \\
Pola Asuh Ibu & & \\
Demokratis & 43 & 43 \\
Otoriter & 28 & 28 \\
Permisif & 16 & 16 \\
Undifferentiated & 13 & 13 \\
\hline
\end{tabular}

Janet Tri Bibelia, Nur Oktavia Hidayati*, Irman Somantri

Fakultas Keperawatan, Universitas Padjadjaran Bandung, Jawa Barat

Korespondensi Penulis: Nur Oktavia Hidayati. *Email: nur.oktavia@unpad.ac.id

DOI: https://doi.org/10.33024/hjk.v15il.4629 
Pola asuh orang tua pada remaja dengan kecanduan internet

Tabel 2. Menunjukkan hasil pola asuh orang tua yang dipersepsikan remaja di SMA Negeri Jatinangor. Dari data yang ada, pola asuh yang dipersepsikan remaja terhadap ayahnya paling banyak adalah pola asuh demokratis, yakni sebanyak $38 \%$. Sebanyak $28 \%$ responden mempersepsikan pola asuh ayah adalah permisif, sebanyak $25 \%$ mempersepsikan pola asuh ayah adalah otoriter, dan sebanyak $9 \%$ responden mempersepsikan pola asuh ayah undiferrentiated. Sama dengan hasil pada kelompok ayah, pola asuh yang dipersepsikan remaja terhadap ibunya paling banyak adalah pola demokratis, yakni sebesar 43\%, sebanyak $28 \%$ responden mempersepsikan pola asuh ibu adalah otoriter, $16 \%$ responden mempersepsikan pola asuh ibu adalah permisif, dan $13 \%$ responden mempersepsikan pola asuh ibu undiferrentiated. Secara umum, pola asuh orang tua yang dipersepsikan remaja adalah pola asuh demokratis.

\section{PEMBAHASAN}

\section{Pola Asuh Ayah}

Dalam pengasuhan remaja, ayah memiliki beberapa peran penting yang harus dipenuhi untuk mendukung anaknya memiliki perilaku yang positif. Secara umum, peran terpenting ayah dalam keluarga adalah sebagai economic provider (Hidayati et al., 2011). Peran tersebut dipenuhi oleh ayah dengan menjadi tulang punggung keluarga untuk memenuhi kebutuhan anak, khususnya kebutuhan secara materi. Selain sebagai tulang punggung keluarga, ayah juga memiliki peran penting dalam berbagai aspek kehidupan remaja. Tingginya tingkat kecanduan internet pada remaja tidak dapat terlepas dari pola asuh ayah yang dipersepsikan oleh anak usia remaja. Hal ini dikarenakan dalam pengasuhan anak, ayah memiliki peran untuk membentuk pribadi anak yang mandiri, bertanggung jawab, percaya diri, dan kompeten (Rakhmawati, 2015).

Berdasarkan hasil penelitian kepada 100 orang responden, didapatkan hasil pola asuh yang dipersepsikan oleh remaja yang kecanduan internet di SMA Negeri Jatinangor didominasi oleh jenis pola asuh demokratis. Hal ini menunjukkan bahwa secara dominan ayah dari remaja yang kecanduan internet di SMA Negeri Jatinangor memberikan kebebasan pada anaknya dalam menggunakan internet, namun tetap memberikan kontrol dan pengawasan.

Hasil penelitian ini sejalan dengan penelitian yang dilakukan oleh (Sulistyo, 2015) yang menunjukkan bahwa permasalahan akibat kecanduan game online justru dimiliki pada anak yang memiliki pola asuh demokratis. Padahal, pola asuh demokratis cenderung mendukung anak untuk memiliki perilaku penggunaan internet yang positif atau tidak mengalami kecanduan internet. Meskipun demikian, lebih dari setengah responden mempersepsikan pola asuh orang tua yang tidak mendukung perilaku yang positif dalam penggunaan internet, yaitu pola asuh permisif (28\%) dan pola asuh otoriter (25\%).

Secara konsep, pola asuh demokratis akan memberikan dampak positif terhadap perilaku anak. Orang tua dengan pola asuh demokratis akan memberikan batasan dan harapan yang jelas terhadap perilaku anak dalam menggunakan internet. Mereka berusaha untuk menyediakan panduan perilaku penggunaan internet yang tepat dengan menggunakan alasan dan aturan serta reward dan punishment secara jelas (Widiastuti \& Elshap, 2015). Kontrol tersebut didukung oleh kehangatan yang diberikan melalui komunikasi yang baik dengan anak sehingga anak cenderung leluasa menyampaikan pendapat dan tidak merasa tertekan dengan kontrol yang diberikan. Pola asuh tersebut diyakini sebagai pola asuh yang paling mendukung remaja untuk tidak mengalami kecanduan internet.

Sebanyak 38\% responden mempersepsikan pola asuh yang dimiliki oleh ayahnya adalah pola asuh yang demokratis. Dari hasil tersebut dapat ditunjukkan bahwa hampir sebagian remaja di SMA Jatinangor yang mengalami kecanduan internet sebenarnya telah memiliki pola asuh yang justru seharusnya mencegah mereka mengalami kecanduan internet. Dalam penelitian ini, keadaan seperti itu kemungkinan terjadi karena kontrol yang kuat namun kurang tepat yang diberikan oleh ayah. Sebanyak $38 \%$ responden dalam penelitian ini memiliki hubungan komunikasi yang baik dengan ayah dalam mendiskusikan peraturan dan harapan mereka terkait penggunaan internet. Dari data tersebut, terlihat bahwa hampir sebagian responden memiliki hubungan kehangatan melalui hubungan komunikasi yang baik dengan ayah.

Walaupun upaya pemberian kontrol dan

Janet Tri Bibelia, Nur Oktavia Hidayati*, Irman Somantri

Fakultas Keperawatan, Universitas Padjadjaran Bandung, Jawa Barat

Korespondensi Penulis: Nur Oktavia Hidayati. *Email: nur.oktavia@unpad.ac.id

DOI: https://doi.org/10.33024/hjk.v15il.4629 
kehangatan telah diberikan oleh ayah, namun sayangnya kemungkinan besar ayah tidak mengetahui secara spesifik terkait penggunaan internet, khususnya terkait intensitas dan durasi penggunaan internet.

Dalam penelitian ini, peneliti yang tidak memodifikasi pernyataan- pernyataan dalam instrumen tentang pola asuh apabila dikaitkan dengan penggunaan internet. Keadaan tersebut menyebabkan responden mempersepsikan pola asuh yang diterima secara umum yang kemungkinan tidak sepenuhnya berkaitan dengan penggunaan internet. Oleh karena itu, tidak dapat diketahui secara spesifik apakah semua pernyataan dalam instrumen menggambarkan pola asuh ayah yang dipersepsikan remaja di SMA Jatinangor terkait dengan perilaku penggunaan internet.

Ketidaktepatan kontrol yang kurang tepat pada ayah dapat disebabkan oleh berbagai faktor, salah satunya adalah pengetahuan. Pengetahuan yang cukup terkait batas-batas penggunaan internet, baik itu secara durasi, intensitas, maupun konten yang diakses dapat mendukung ayah untuk memberikan kontrol penggunaan internet yang tepat pada remaja. Sejalan dengan penelitian yang dilakukan oleh Bleakley, Ellithorpe, \& Romer (2016) yang menyatakan bahwa pengetahuan orang tua sangat penting dalam melakukan pengawasan yang tepat terhadap penggunaan internet remaja. Dalam penelitian ini, hanya 8 orang responden yang memiliki ayah dengan latar belakang pendidikan tinggi sedangkan sisanya memiliki ayah dengan latar belakang pendidikan dasar dan menengah. Sehingga dapat disimpulkan bahwa kemungkinan ayah responden dalam penelitian ini tidak memiliki informasi yang cukup tentang kontrol seperti apa yang harus diberikan untuk mencegah remaja mengalami kecanduan internet.

Meskipun pola asuh demokratis lebih banyak dipersepsikan jika dibandingkan dengan 2 pola asuh lainnya, namun tidak dapat dipungkiri bahwa remaja yang mempersepsikan pola asuh yang tidak mendukung perilaku penggunaan internet secara positif berjumlah jauh lebih besar. Sebanyak $25 \%$ responden mempersepsikan pola asuh ayah otoriter dan sebanyak $28 \%$ responden mempersepsikan pola asuh ayah permisif. Kedua pola asuh tersebut cenderung mendorong remaja untuk mengalami kecanduan internet.

Pola asuh otoriter dimiliki oleh orang tua yang memiliki kontrol terlalu tinggi dan hanya sedikit memberikan kehangatan dalam hubungan dengan anak. Pola asuh ini cenderung memaksa anak untuk bertindak disiplin. Ayah dengan pola asuh otoriter cenderung tidak mau berdiskusi dengan anak tentang harapan dan peraturan pengunaan internet sehingga anak dipaksa untuk mengikuti peraturan dan standar yang ditetapkan hanya oleh orang tua. Remaja pada akhirnya melampiaskan perasaan kecewa yang timbul akibat ketidakhangatan keluarga dengan meningkatkan aktivitas online seperti bermain game online sehingga pada akhirnya mendorong remaja untuk semakin mengalami kecanduan internet (Kusumawati, Aviani \& Molina, 2017).

Ketidakhangatan yang tidak diberikan oleh ayah dengan pola asuh otoriter juga menyebabkan anak memiliki komunikasi antara ayah dan anak yang buruk sehingga melampiaskannya melalui penggunaan internet yang tidak sesuai. Keadaan tersebut sejalan dengan penelitian yang dilakukan oleh Valcke, Bonte, Wever, \& Rots (2010) yang menyatakan bahwa pola asuh otoriter menyebabkan anak menjadi enggan untuk bertanya dan berdikusi terkait penggunaan internet sehingga dengan berbagai cara ia akan berusaha memenuhi keinginannya untuk mengakses internet tanpa batas.

Sebanyak 28\% responden mempersepsikan pola asuh ayah yang diterima adalah pola asuh permisif. Pola asuh permisif cenderung memberikan kebebasan pada remaja untuk mengakses internet. Tidak ada tuntutan yang berarti yang diberikan ayah pada anak dalam menggunakan internet dan tidak ada hukuman yang akan diberikan apabila anak melakukan kesalahan atau penyimpangan dalam penggunaan internet. Kecenderungan ayah menerapkan pola asuh permisif kemungkinan disebabkan oleh status pekerjaan. Ayah yang umumnya menjadi tulang punggung keluarga cenderung tidak memiliki waktu untuk berdiskusi dan memberikan kontrol adekuat pada anak (Kusumawati et al., 2017). Dalam penelitian yang dilakukan oleh Widiastuti dan Elshap (2015), sebanyak 47\% remaja yang memiliki perilaku kecanduan internet ternyata memiliki pola asuh permisif. Selain mengalami kecanduan karena dapat mengakses internet

Janet Tri Bibelia, Nur Oktavia Hidayati*, Irman Somantri

Fakultas Keperawatan, Universitas Padjadjaran Bandung, Jawa Barat

Korespondensi Penulis: Nur Oktavia Hidayati. *Email: nur.oktavia@unpad.ac.id

DOI: https://doi.org/10.33024/hjk.v15il.4629 
tanpa adanya peraturan waktu dan intensitas, anak dengan pola asuh permisif juga akan berisiko untuk mengalami gangguan psikologis lain seperti depresi, kecanduan pornografi, atau ketidakmampuan untuk berinteraksi secara sosial. Hal tersebut diakibatkan oleh konten-konten internet yang tidak dibatasi yang pada akhirnya diterima oleh remaja tanpa ada pengawasan dan kontrol dari orang tua.

Sebanyak $9 \%$ atau hanya sebagian kecil responden dalam penelitian ini yang mempersepsikan pola asuh ayah yang diterimanya sebagai pola asuh undiferrentiated. Pola asuh ini terbentuk apabila responden mempersepsikan dua jenis pola asuh ayah yang sama kuat. Dua pola asuh yang dipersepsikan dapat berupa pola asuh yang mendukung dan pola asuh yang tidak mendukung atau pola asuh yang sama-sama tidak mendukung perilaku remaja yang sesuai dalam penggunaan internet. Dengan demikian, remaja yang mempersepsikan pola asuh ayah undifferentiated juga memiliki kecenderungan untuk mengalami kecanduan internet. Kecanduan internet dapat semakin tinggi kemungkinannya apabila pola asuh yang dipersepsikan merupakan dua pola asuh yang tidak mendukung, yakni pola asuh otoriter dan pola asuh permisif.

\section{Pola Asuh Ibu}

Ibu memiliki banyak sekali peran krusial dalam tahap tumbuh kembang anak, terlebih saat anak memasuki usia remaja. Kecenderungan ibu sebagai sosok yang lebih sering menghabiskan waktu dengan anak menjadi alasan mengapa penting bagi seorang ibu untuk menerapkan pola asuh yang sesuai dalam rangka mencegah terjadinya perilaku kecanduan internet.

Dalam penelitian ini, $43 \%$ ibu memiliki gambaran pola asuh demokratis. Jumlah tersebut lebih besar apabila dibandingkan dengan jumlah ayah yang dipersepsikan memiliki pola asuh yang demokratis. Sama seperti penjelasan yang telah diberikan sebelumnya, secara konsep pola asuh ini seharusnya mendukung seorang anak untuk tidak mengalami kecanduan.

Pola asuh demokratis yang dipersepsikan oleh remaja yang mengalami kecanduan internet lagilagi kemungkinan terjadi karena kontrol yang kuat namun kurang tepat. Keadaan tersebut dapat juga terjadi karena data latar pendidikan ibu yang umumnya rendah. Hasil penelitian menunjukkan bahwa $58 \%$ responden memiliki ibu dengan latar belakang pendidikan dasar, 40\% latar belakang pendidikan menengah, dan hanya $2 \%$ ibu yang memiliki latar belakang pendidikan tinggi. Rendahnya tingkat pendidikan kemungkinan menjadi alasan mengapa pola asuh demokratis yang diterapkan oleh ibu pada responden penelitian ini sebenarnya adalah pola asuh demokratis yang kurang tepat.

Terdapat $28 \%$ responden yang mempersepsikan pola asuh ibu sebagai pola asuh otoriter. Kecenderungan ibu untuk melakukan kontrol secara dominan kemungkinan terjadi karena beberapa alasan. Pertama, ibu sebagai seorang perempuan memiliki kecenderungan untuk lebih mengontrol anggota keluarganya terutama anak remaja. Pernyataan tersebut sejalan dengan penelitian Valcke et al. (2010) yang menunjukkan bahwa wanita umumnya memiliki kontrol organisasi yang lebih kuat dalam memberikan pengasuhan. Selain itu, ibu juga cenderung memiliki waktu yang lebih banyak untuk menghabiskan waktu bersama anak dibandingkan dengan ayah. Hanya $16 \%$ ibu yang memiliki gambaran pola asuh permisif. Ibu yang permisif cenderung memberikan kebebasan berlebih, khususnya terkait penggunaan internet sehingga membuat remaja tidak mengetahui apakah perbuatan yang ia lakukan itu benar atau salah. Pola asuh ini membuat hubungan anak dan ibu penuh dengan kasih sayang (kehangatan) namun anak menjadi agresif dan hanya mengikuti kata hatinya (Sanjiwani \& Budisetyani, 2014). Dalam perilaku penggunaan internet, anak yang mempersepsikan pola asuh ibunya adalah permisif akan memenuhi kepuasan dirinya dengan menggunakan internet tanpa batas. Ibu dengan tingkat pengetahuan yang rendah berisiko tidak mengetahui batas-batas penggunaan internet dan dampak buruk apa yang diberikan apabila anaknya mengalami kecanduan internet. pengaruh pola asuh ibu yang permisif terhadap perilaku remaja yang buruk dibuktikan oleh penelitian yang dilakukan oleh Sanjiwani \& Budisetyani (2014) dimana pola asuh ibu permisif memiliki hubungan kuat dengan perilaku remaja yang merokok.

Terdapat $13 \%$ responden yang mempersepsikan pola asuh ibu sebagai pola asuh undifferentiated. Hal tersebut menunjukkan bahwa

Janet Tri Bibelia, Nur Oktavia Hidayati*, Irman Somantri

Fakultas Keperawatan, Universitas Padjadjaran Bandung, Jawa Barat

Korespondensi Penulis: Nur Oktavia Hidayati. *Email: nur.oktavia@unpad.ac.id

DOl: https://doi.org/10.33024/hjk.v15il.4629 
cukup banyak responden yang mempersepsikan ibunya menerapkan 2 jenis pola asuh yang sama kuat. Kecenderungan ibu dalam menerapkan salah satu pola asuh yang dominan ini memungkinkan anak untuk tidak memiliki perilaku penggunaan internet yang juga tidak konsisten. Anak usia remaja yang sedang mengalami fase transisi dan mengalami banyak gejolak emosional menjadi kemungkinan faktor penyebab mengapa terdapat ibu yang dipersepsikan tidak menerapkan salah satu pola asuh secara dominan.

Dalam penelitian yang dilakukan, pola asuh ayah dan ibu yang paling banyak dipersepsikan adalah pola asuh demokratis. Pola asuh ayah dan ibu yang dipersepsikan oleh anak usia remaja yang mengalami kecanduan internet sebagai responden penelitian ini paling banyak adalah pola asuh demokratis. Keadaan tersebut bertolak belakang dari konsep yang telah dipaparkan dimana pola asuh demokratis cenderung mendukung seorang anak untuk memiliki perilaku yang baik. Pada kelompok responden yang mempersepsikan pola asuh ayah dan ibu adalah pola asuh yang demokratis, perilaku kecanduan internet kemungkinan disebabkan oleh faktor lain yang lebih kuat selain pola asuh orang tua.

\section{SIMPULAN}

Berdasarkan hasil penelitian yang dilakukan, responden remaja yang mengalami kecanduan internet di SMAN Jatinangor mempersepsikan beragam jenis pola asuh orang tua yang diterapkan. Pada sisi ayah, siswa paling banyak mempersepsikan pola asuh yang diterapkan adalah pola asuh demokratis, yakni sebanyak $38 \%$ responden. Hal yang sama juga terjadi pada sisi ibu dimana 43\% responden mempersepsikan pola asuh ibunya adalah pola asuh demokratis.

\section{SARAN}

Pihak sekolah dapat bekerjasama dengan orang tua murid dalam melakukan pemantauan pemakaian internet, melakukan pendidikan kesehatan dan layanan konseling terkait kecanduan internet dan peran orang tua dalam mencegah perilaku kecanduan internet, untuk penelitian selanjutnya diharapkan dapat meneliti lebih lanjut hubungan pola asuh dan perilaku kecanduan internet.

\section{DAFTAR PUSTAKA}

Asosiasi Penyelenggara Jasa Internet Indonesia. (2014). Profil pengguna internet Indonesia. Jakarta.

Asosiasi Penyelenggara Jasa Internet Indonesia. (2017). Penetrasi dan perilaku pengguna internet Indonesia. Jakarta.

Astuti, V. (2013). Keterlibatan ayah dalam pengasuhan jarak jauh remaja. In Prosiding Seminar Nasional Parenting (pp. 121-131).

Bleakley, A., Ellithorpe, M., \& Romer, D. (2016). The role of parents in problematic internet use among US adolescents. Media and Communication, 4(3), 24-34. https://doi.org/10.17645/mac.v4i3.523

Elia, H. (2009). Kecanduan berinternet dan prinsipprinsip untuk menolong pecandu internet. Veritas, 10(2), 285-299.

Hakim, S. N., Raj, A. A., Febrian, D., \& Prastiwi, C. (2016). Remaja dan internet. In Semnas Penguatan Individu di Era Revolusi Informasi Penguatan Individu di Era Revolusi Informasi (pp. 311-319). Surakarta.

Henry, R. (2010). The association between perceived parenting styles and adolescent substance use. Mini thesis. University of the Western Cape.

Hidayati, F., Veronika, D., \& Kaloeti, S. (2011). Peran ayah dalam pengasuhan anak. Jurnal Psikologi Undip, 9(1), 1-10.

Huang, L. (2009). A qualitative analysis of influential factors on Internet use among vocational college students. Central South University.

Kusumawati, R., Aviani, Y. I., \& Molina, Y. (2017). Perbedaan tingkat kecanduan (adiksi) games online pada remaja ditinjau dari gaya pengasuhan. RAP UNP, 8(1), 88-99. 
Lam, L. T., Peng, Z., Mai, J., \& Jing, J. (2009). Factors associated with internet addiction among adolescents. CyberPsychology \& Behavior, 12(5), 551-555. https://doi.org/10.1089/cpb.2009.0036

Masya, H., \& Candra, D. A. (2016). Faktor-faktor yang mempengaruhi perilaku gangguan kecanduan game online pada peserta didik kelas $\mathrm{x}$ di madrasah aliyah al furqon prabumulih tahun pelajaran 2015/2016. Jurnal Bimbingan Dan Konseling, 03(1), 153-169. Retrieved from https://ejournal.radenintan.ac.id/index.php/kons eli

Mintz, G., Etengoff, C., \& Grysman, A. (2017). The relation between childhood parenting and emerging adults" experiences of shame and guilt. Journal of Child and Family Studies, 26(1), 2908-2920. Retrieved from https://doi.org/gbx6ks

Morrish, J. (2011). Parental influence on youth behaviours. Ontario Injury Prevention Resource Centre.

Novianty, D. D. (2018). Gambaran penggunaan dan tingkat kecanduan internet pada siswasiswi SMA $X$ di Jatinangor. (Skripsi., Universitas Padjadjaran).

Qomariyah, A. N. (2009). Perilaku penggunaan internet pada kalangan remaja di perkotaan. Jurnal Kesehatan Indonesia, 1(1), 15. https://doi.org/10.1080/03630260601059225

Rakhmawati, I. (2015). Peran keluarga dalam pengasuhan anak. Bimbingan Konseling Islam, 6(1), 1-18.

Rini, A. (2011). Menanggulangi Kecanduan Game Online pada Anak. Jakarta: Pustaka Mina.

Sanjiwani, N. L. P. Y., \& Budisetyani, I. G. A. P. W. (2014). Pola asuh permisif ibu dan perilaku merokok pada remaja laki-laki di SMA Negeri 1 Semarapura. Jurnal Psikologi Udayana, 1(2), 344-352.
Sarwono, S. (2011). Psikologi remaja. Jakarta: Rajawali Pers.

Sulistyo, J. T. (2015). Hubungan problematic online game use dengan pola asuh pada remaja. Jurnal Psikologi Ulayat, 2(1), 396-406.

Trumello, C., Babore, A., Candelori, C., Morelli, M., \& Bianchi, D. (2018). Relationship with parents , emotion regulation, and callous-unemotional traits in adolescents " internet addiction. BioMed Research International, 2018(1), 10.

Turkle, S. (2011). Alone Together: Why We Expect More from Technology and Less from Each Other. New York: Basic Book.

Valcke, M., Bonte, S., Wever, B. De, \& Rots, I. (2010). Internet parenting styles and the impact on internet use of primary school children. Computers \& Education, 55(2), 454-464. https://doi.org/10.1016/i.compedu.2010.02.00

Wąsiński, A., \& Tomczyk, Ł. (2015). Factors reducing the risk of internet addiction in young people in their home environment. Children and Youth Services Review, 57, 68-74. https://doi.org/10.1016/j.childyouth.2015.07.02

Widiastuti, N., \& Elshap, D. S. (2015). Pola asuh orang tua sebagai upaya menumbuhkan sikap tanggung jawab pada anak dalam menggunakan teknologi komunikasi. Jurnal IImiah UPT P2M STKIP Siliwangi, 2(2), 148159.

Yamawaki, N., Peterson, J. A., \& Omori, M. (2011). Self-esteem and life satisfaction as mediators between parental bonding and psychological well- being in Japanese young adults. International Journal of Psychology and Counselling, 3(1), 1-8.

Yang, X., Zhu, L., Chen, Q., Song, P., \& Wang, Z. (2016). Parent marital conflict and internet addiction among Chinese college students: the mediating role of father-child, mother-child, and peer attachment. Computers in Human Behavior, 59(1), 221-229. https://doi.org/10.1016/j.chb.2016.01.041

Janet Tri Bibelia, Nur Oktavia Hidayati*, Irman Somantri

Fakultas Keperawatan, Universitas Padjadjaran Bandung, Jawa Barat

Korespondensi Penulis: Nur Oktavia Hidayati. *Email: nur.oktavia@unpad.ac.id 